\title{
Transformational Leadership and Job Satisfaction: The Case of Secondary Education Teachers in Greece
}

\author{
Zacharo Kouni ${ }^{1}$, Marios Koutsoukos ${ }^{2}$, Dimitra Panta ${ }^{3}$ \\ ${ }^{1}$ Secondary Education Professor M.Ed., Thessaloniki, Greece \\ ${ }^{2}$ Ass, Professor ASPETE, School of Pedagogical and Technological Education, Greece \\ ${ }^{3}$ Professor ASPETE, School of Pedagogical and Technological Education, Greece \\ Correspondence: Zacharo Kouni, Secondary Education Professor M.Ed., Thessaloniki, Greece. \\ E-mail: zahkouni@gmail.com
}

Received: July 17, 2018

Accepted: September 4, 2018

Online Published: September 12, 2018

doi:10.11114/jets.v6i10.3451

URL: https://doi.org/10.11114/jets.v6i10.3451

\begin{abstract}
In international literature there are many documented studies which have shown the relationship between leadership and job satisfaction. Specifically, transformational leadership is highly associated with this important and positive work attitude, that is, job satisfaction. The interpretation in a school context is that the director should operate as transformational leader so as to produce better educational outcomes through teachers' job satisfaction. In Greece, little empirical research has been done to investigate the perceptions of teachers about the relationship between transformational leadership and job satisfaction of teachers. The purpose of the present study is to investigate the perceptions of teachers to the extent that transformational leadership contributes to job satisfaction. The selected research method is a combination of quantitative and qualitative methods, namely using the questionnaire and the interview. The sample consisted of 171 teachers from two types of educational institutions, secondary junior high schools and high schools, of a local directorate of secondary education. The survey results showed that teachers feel substantial satisfaction when the school principal acts as a transformational leader. Demographic variables, the type of school, and work experience, do not affect the views of teachers.
\end{abstract}

Keywords: leadership, transformational leadership, job satisfaction, junior high school and high school teachers

\section{Introduction}

\subsection{Introduction to the Problem}

The modern environment, within which a school organization operates, is characterized by dynamic development. As a result, this represents a challenge for the school organization, in order for it to be able to respond to changes with flexibility and determination, and establish a positive outlook, thus avoiding stagnation. Therefore, it is an imperative need for leaders/principals to possess an appealing and charismatic personality, combined with a strong influence and a broad vision; these leaders should be able to ignite enthusiasm among teachers and inspire them toreach optimum utilization of their skills and capabilities, as well as experience a high level of job satisfaction. Those principals who manifest this type of characteristics and attitudes are transformational leaders.

According to international research data, it is shown that when transformational leadership is effectively applied to educational organizations, it has a positive impact on schooling conditions, as well as on teachers' internal states and behaviors, also contributing to their job satisfaction (Leithwood \& Jantzi, 2000; Leithwood \& Jantzi 1999a; Leithwood, Jantzi \& Steinbach, 1999b; Leithwood \& Sun 2012; Meng \& Chin, 2007). Moreover, the degree of the teacher's satisfaction with his or her job can have a decisive effect on his or her life, as well as on the lives of others, and especially on his or her students, since the job satisfaction of teachers show a strong correlation with student performance and progress (Griffin, 2010; Hutabarat, 2015).

In this article, an investigation takes place on the views held by teachers about the association between their job satisfaction and the transformational leadership model in school. 


\section{Theoretical Context of Transformational Leadership}

Transformational leadership has attracted the attention of many researchers who specialize in the field of leadership within organizations (Bass \& Riggio, 2014; Givens, 2008). Therefore, research has shown that the application of transformational leadership to organizations yields positive results. These results refer to either the organization itself (performance, culture, vision) or its members (empowerment, job satisfaction, commitment, trust, self-efficacy, beliefs, and incentives/motivation) (Given, 2008; Tucker \& Russell, 2004). It is a contemporary leadership theory that studies key personal traits, which are fostered and developed by the leader, in order for him or her to be able to inspire and influence his or her followers and lead effectively (Robbins \& Judge, 2011; Vakola \& Nikolaou, 2012).

The relationship between leader and follower is placed by the advocate of this theory, MacGregor Burns, on the basis of ethics, with the leader being able to understand the ethical and moral values of followers, in order to guide them, both conscientiously and emotionally, towards reaching the goal of organizational restructuring and reform (Tosi, Mero \& Rizzo, 2000; Yukl 2010). From this perspective, transformational leadership can be characterized as ethical leadership, since it strengthens human contact and fosters motivation and ethical willingness in the leader and the followers, in order for them to work synergistically to achieve the organizational goals (Kantas, 1993; Kanungo, 2001). In this context, a leader seeks to comprehend and satisfy the higher-level needs of his or her followers, offer them incentives to strive and improve their practices and boost their self-esteem, and finally help them achieve superior goals (Bass, 1985; Bass et al., 2014; Kanungo, 2001; Leithwood, 1992; Vecchio, 1995).

\subsection{Transformational Leadership in Education}

Transformational leadership is also successfully applied to educational organizations, since research data show that it has a positive impact on schooling conditions, on teachers' internal states and behaviors and their job satisfaction, as well as on student performance and progress (Leithwood et al., 2012; Leithwood et al., 2000; Meng et al., 2007). The practices and behaviors of transformational school leaders have been investigated by Leithwood and his colleagues, who adapted school management to the theoretical models of transformational leadership that were developed and operated in non-school settings (Geijsel, Sleegers, Leithwood \& Jantzi, 2002; Jantzi \& Leithwood, 1995; Leithwood et al., 1999b; Theofilidis, 2012).

From relevant research that has been conducted, three general characteristics-categories of transformational leadership have emerged: setting direction-orientation, human resources development, and organizational restructuring (Geijsel et al., 2002; Jantzi \& Leithwood, 1996; Leithwood \& Beatty, 2008; Leithwood et al., 1999b).

-Setting direction-orientation. This refers to building a shared vision on school values, accepting the common goals that have been set by the teachers and leader/principal, and the high teacher performance expectations being set by the leader.

-Human resources development. This refers to the provision of individualized support by the school leader to the teachers, as well as causing their intellectual stimulation, in order for the latter to be able to reflect on and try new learning and teaching approaches, with the leader serving as a role model and providing the key values.

-Organizational restructuring. This refers to strengthening the culture - establishing common standards, assumptions, beliefs, and values, so that the operation of the organization is focused on meeting the students' needs and building partnerships and cooperation that are oriented towards reaching the common goals set by the school, as well as facilitating autonomous decision-making by teachers or their groups, in order to provide solutions to problems related to teaching and learning issues.

The nature of the educational system seems to play a decisive role in the implementation of such a model in schools. In Greece, for example, where the educational system is centrally planned and bureaucratic, the views of experts on the implementation of the model are divided. A number of scholars argue that "transformational leadership lacks the potential to emerge through the existing structured operation" (Raptis, 2006, p. 36), whereas some of them accept that "there is room to apply its principles especially to school units that have adapted their operation according to the cooperative management model (Katsaros, 2008, p. 109)". Furthermore, several researchers argue that transformational leadership is currently a "new trend in educational systems, after many years of adherence to the bureaucratic system (Vasileiadou \& Dieronitou, 2014, p. 103)".

\section{Theoretical Context of Job Satisfaction}

Several researchers maintain that job satisfaction and motivation, although different concepts, are so closely related, that they can be included in the same theoretical context (Lowenberg \& Conrad, 1998; Mullins, 2007). Motivation and job satisfaction have a special relationship which aims, on the one hand, to satisfy the person's need to feel that it offers significant work to an organization, and on the other hand, to help the leader realize this need and motivate the person (Reppa, 2008). 
Motivation activates the individual's behavior through the provision of incentives, and guides it towards goal achievement, in order to satisfy the individual's needs in the workplace (Bourantas, 1992; Lowenberg et al., 1998; Reppa, 2008). The goals of the organization are implemented successfully when one or more needs of the individual are satisfied at the same time (Theofilidis, 2012). Hence, motivation is linked to performance and job satisfaction, and it is important for management executives to know what motivates and activates employees, in order for them to carry out their duties in an optimum way (Isac \& Badshah, 2016; Kefis, 2005; Mullins, 2007).

The motivation theories that are cited in literature, and which attempt to interpret job satisfaction, are normally divided into the following key categories: content theories and process theories (Bourantas, 1992; Mullins, 2007; Saif, Nawaz, Jan and Khan, 2012; Tosi et al., 2000; Vakola et al., 2012; Vecchio, 1995). The most popular theories that belong to the first category are: Maslow's Hierarchy of Needs Theory, the ERG motivation Theory by Aldefer, Herzberg's Two Factor Theory, Theory X and Theory Y Theory by McGregor, and the Theory of Needs-Achievement motivation theory by McClelland. On the other hand, the most well-known theories from the second category are: the Equity Theory by Adams, the Expectancy Theory by Vroom, the Goal-Setting Theory, the Job Characteristics Model and the Social Learning Theory by Bandura.

All theories agree that a capable leader tries to understand human behavior and apply powerful and effective motivation, by acknowledging the employee as the main source of quality and efficiency, capable of taking action and achieving success. Knowing why and how individuals are motivated is an important advantage for a leader, when he or she aims to improve the job satisfaction experienced by those individuals.

Within the context of this study, job satisfaction is interpreted as the positive feeling that is expressed by an individual for his or her job, when he or she evaluates its characteristics and results on the basis of the needs, incentives, values or goals that he or she considers as important (Drenth, Thierry \& Wolff, 1998; Robbins et al., 2011).

\subsection{Teachers' Job Satisfaction}

Teachers' satisfaction with their profession is a major issue, since it affects how each teacher carries out his or her role, which reflects on the quality of his or her teaching work and the school operation (Ostroff, 1992). The level of the teacher's satisfaction with his or her job can have a decisive impact on both his or her life and the lives of others, and especially on his or her students, since the job satisfaction of the teacher shows a strong correlation to the achievement of the latter (Griffin, 2010; Hutabarat, 2015).

Covering material or mental and emotional needs is directly linked to the level of the teacher's job satisfaction and (Kampouridis, 2002). Only scientific research has the potential to identify the specific characteristics of the teaching profession that satisfy the teachers' needs and motivate them; scientific research can also highlight those factors that increase job satisfaction or dissatisfaction (Bolin, 2008).

In recent years, the job satisfaction of teachers has emerged as a subject that has drawn the attention of researchers (Chamundeswari, 2013). As a result, there is a series of both international and Greek research data that reveal the factors that can affect the job satisfaction teachers. These factors are demographic (gender, age, professional experience, level of education), external (remuneration, workplace relations), or internal (achievement, autonomy, professional development, recognition of work, responsibility).

In a survey conducted by Saiti and Papadopoulos (2015), it was found out that a stable job, their relationship with the school's management and their colleagues, and the nature of the job itself, affect the level of satisfaction experienced by primary education teachers. In the same survey, it was shown that the remuneration offered to cover material needs does not affect the job satisfaction experienced by teachers, although their salaries have been significantly reduced due to the deep recession that the country is currently going through.

A very satisfactory level of communication and relationship between teacher and student has a positive impact on the satisfaction experienced by the teacher with his or her profession, as shown inthe results of a survey that was conducted by Golia (2014) on primary and secondary education teachers, with female teachers expressing a higher level of satisfaction. This finding confirms an earlier survey conducted by Zournatzi, Tsiggilis, Koustelios, and Pintzopoulou (2006), who discovered that a high level of job satisfaction is experienced by physical education teachers serving in primary education, as a result of their enhanced emotional bonding with their pupils. Similar conclusions can also be found in surveys conducted internationally, where the teacher-students relationship affects their self-esteem and mental health (Spilt, Koomen \& Thijs, 2011).

Eliophotou and Reppa (2011) conducted a survey on secondary education teachers and explored seven aspects of job satisfaction, in relation to the gender and experience of teachers. These seven aspects included the school climate, key stakeholders in the educational process (parents, students, and the community), support provided to the teacher in his or her work, as well as opportunities for further training, participation in management, student and school effectiveness, 
professional development, and terms of employment (salary and term of employment). The survey demonstrated the fact that teachers with longer experience enjoy more satisfaction with their profession, regardless of their gender, and more specifically, as a result of their contact with the stakeholders and their participation in the school's management.

In a survey conducted by the OECD in 2013 (OECD, 2014), on lower secondary education teachers from 30 countries, it was shown that, overall, teachers experience satisfaction with their job, with the most important factors that determine this satisfaction being the level of cooperation among teachers, their positive relationship with their students, and their participation in decision-making. Moreover, in a survey conducted by Bentea and Anghelache (2012) through the participation of teachers from all levels of education, it was found out that the job satisfaction of teachers results from the satisfaction of their needs for achievement, recognition, and social relationships, since they believe that the principal acknowledges their teaching skills, there is a good level of communication in the school. Moreover, their employment status, which is estimated on the basis of further training that they receive towards their professional development, serves as a factor that determines job satisfaction.

\section{The Relationship Between Transformational Leadership and Job Satisfaction Experienced by Teachers}

Arguments found in modern literature on the subject favor the view that successful companies and effective schools are run by leaders who establish those workplace conditions that enable employees to experience emotions of satisfaction (Adams \& Bailey, 1989). Currently, ensuring employee satisfaction has been elevated to one of the most important duties that should be carried out by those who manage organizations (Aydin, Sarier \& Uysal, 2013). On those grounds, there has been ongoing research on the relationship between leadership and job satisfaction, and the researchers' interest has remained strong.

Although there are relatively few studies that investigate the relationship between transformational leadership and the level of job satisfaction experienced by teachers (Eliophotou \& Ioannou, 2016; Nguni, Sleegers \& Denessen, 2006), their findings are particularly interesting.

In a survey conducted by Sayadi (2016) on a sample of 387 teachers for 42 primary and secondary education school in Iran, aiming to investigate the implications of transformational leadership in job satisfaction and commitment to the organization, the results demonstrated the fact that the relationship between the principal and the teacher plays the role of both external and internal motivation towards stronger job satisfaction experienced by the teacher. The teacher's trust in the principal's judgment, as well as in the values advocated by the latter, combined with the mission of the school, establish an emotional bond with the leadership, which is associated with job satisfaction. Similar findings have resulted from the survey of Tesfaw (2014) about the relationship between transformational leadership and the job satisfaction of teachers, which was conducted on a sample of 320 teachers from 20 secondary education schools in Ethiopia, where the behavior of the transformational principal appeared to have a strong correlation with the job satisfaction experienced by teachers. Through his or her charismatic behavior, a transformational principal can become a role model for teachers, earn their admiration and trust, and maintain two-way communication and a commitment culture to all the shared goals of the school.

Eliophotou (2014), in her investigation of the relationship between transformational leadership, the views held by teachers about the effectiveness of the principal/leader, and the job satisfaction experienced by teachers, which was conducted on a sample of 438 teachers from 348 secondary education schools in Cyprus, concluded that, in cases of a high level of overall job satisfaction, teachers recognize the qualitative traits of a transformational and transactional leader in the face of their principal. This finding is highly interesting, bearing in mind that a centrally planned educational system does not allow the application of transformational leadership to the management of schools, to the extent that it has been reported in other countries. In a survey conducted by Golia (2014) on a sample of 640teachers from 77 primary and secondary education school in Northern, Central, and Southern Greece, it was found out that a transformational leader can have a direct impact on the job satisfaction of teachers, since he or she can strengthen the principal-teacher and student-teacher relationships, as well as the relationships that develop among teachers, thus establishing satisfactory workplace conditions.

In their attempt to perform a meta-analysis of twelve surveys about the influence of the type of school leadership in the organizational commitment and job satisfaction of teachers, Aydin et al. (2013) reached the conclusion of the positive influence that a transformational leader can have on job satisfaction, by motivating teachers to act towards the achievement of the school's goals and showing special attention to them.

Nguni et al. (2006) investigated the influence of transformational leadership on job satisfaction, organizational commitment, and organizational citizenship behavior on a sample of 700 primary educational teachers in Tanzania. From the analysis of data, it emerged that transformational leadership has a positive influence on job satisfaction, thus confirming the results and findings of earlier surveys. More specifically, according to the qualitative survey conducted by Barnett, Marsh, and Craven (2005) that was conducted on three secondary educational schools, it was shown that teachers expressed a higher level of satisfaction with the personalized interest demonstrated by the leader, rather than with behaviors pertaining to a visionary 
leader, teaching as a profession, and the leader's place as a role model in the school's daily routine. Moreover, the leader's presence close to the teachers on a daily basis, made the latter feel content, accept, and follow the former.

What is more, in a survey conducted by Griffith (2004) on a sample of 458 teachers from 52 primary education schools in Australia, it was shown that there is an important positive and strong correlation between transformational leadership in schools where leadership can be characterized as transformational, and the job satisfaction of teachers. In the same schools, teachers had achieved a higher level of progress in their job.

\section{Method}

\subsection{Research Objective}

The research objective of this survey is to contribute to the concern that is raised with regard to the influence of transformational leadership in the job satisfaction of teachers.

More specifically, it aims to investigate the views of teachers about the relationship between transformational leadership and the general job satisfaction that teachers experience.

\subsection{Research Questions}

It attempted to provide answers to the following research questions:

1. To what extent do teachers believe that transformational leadership contributes to job satisfaction?

2. Are views divided over whether transformational leadership contributes to job satisfaction according to the years of previous experience?

3. Are views divided over whether transformational leadership contributes to job satisfaction according to the type of school?

\subsection{Sample}

The sample of quantitative survey, which was selected randomly, consisted of secondary junior high school and high school teachers serving at schools of Eastern Thessaloniki. Thus, from the teachers registered at the Teachers' Record of Eastern Thessaloniki, 171 teachers participated, 72 of whom served in junior high schools (a percentage rate of 42\%), and 99 in high schools (a percentage rate of 58\%). In order to conduct the qualitative survey, interviews were taken from 10 permanent teachers who serve at secondary and high schools, where the quantitative survey was conducted.

\subsection{The Questionnaire}

At the stage of quantitative research, the questionnaire method was used as it is one of the most widespread and popular research methods for gathering data (Robson, 2011). The questionnaire was developed specifically for the purpose of this case study, based on literature review, the research's main objective and the conclusions of the qualitative interviews.

In particular, the questionnaire of the survey included three sections of questions:

a) The first section contained 2 questions relating to the size and type of the school unit (secondary of high school).

b) The second section contained 5 questions relating to demographic data (gender, age, qualifications, employment relationships, overall teaching experience) of the subjects of the sample, and

c) The third section contained 27 question-statements in seven conceptual categories-groups, which refer to the behaviors and practices of the transformational school leaders, and which may affect the general job satisfaction of teachers. The question-statements are closed-ended and marked against a grading scale: $1=$ to a minimum extent, $2=$ to a small extent, $3=$ to a moderate extent, $4=$ to a large extent, $5=$ to a maximum extent.

\subsection{The Interviews}

The interview was chosen as a research tool since it examines issues in an in-depth manner and provides detailed information regarding personal opinions and perceptions leading, in this way, to a kind of understanding not easily achieved using quantitative methods (Robson, 2011). More specifically, in this research the interview was structured on three thematic axes:

1st thematic axis: personal details of the responding teacher

2nd thematic axis: exploring the views about the general behaviors of a male or female school principal that contribute to the teacher's general job satisfaction

3rd thematic axis: exploring the views about the most important behaviors of a male or female school principal that contribute to the teacher's general job satisfaction. 
The interviews had an average duration of one hour, were tape-recorded and the useful conclusions deduced were utilized as supplementary material for the final design of the questionnaire which was used at a later step.

\subsection{Research Validity and Reliability}

Research validity and reliability were ensured from the beginning through the use of a multi-method approach (triangulation). Additionally, a higher content validity of the questions, and their reliability and better adaptation to the operating context of the Greek school (Cohen, Manion \& Morisson, 2008) were ensured by a pilot application of the questionnaire to subjects who were not going to participate in the final survey. The final survey was conducted between March and April 2017, and the statistical processing of data was performed by the SPSS 20 statistical package, which is the most appropriate one for social data and surveys conducted through the use of a questionnaire (Dafermos, 2011). In all the statistical tests of hypotheses for generalization over the population, a maximum error possibility of $\alpha=0.05$ was determined as the significance level of the test (Jacobson, 1976). Each hypothesis would be rejected if possibility $\mathrm{P}$ (p-value) was lower than 0.05 .

With regard to the reliability and consistency of the questionnaire, the Cronbach's alpha reliability and internal consistency coefficient was referred to/applied. It was found that alpha $=0.934$ ( $\mathrm{N}=27$ questions). The values are extremely high and satisfactory. Therefore, it can be confirmed that there are not any positive and negative correlations at the same time. Regarding whether it was necessary to exclude a question from the questionnaire, in order to increase the value of alpha, which is something extremely detailed compared to its original value, no significant increase was identified for excluding a question, and in most cases, the coefficient was lower or extremely close to the total (Field, 2009).

In order to practically ensure a degree of validity for the interview, it was attempted to reduce any causes of bias by recording the views of the respondents, as they were expressed, and without looking for answers that would support the predispositions of the researchers (Cohen et al., 2008). The reliability of the interview was pursued through the structured nature of the questions asked to all the respondents, without any changes in the verbal expression of the questions or the use of emphasis (Cohen et al., 2008). Moreover, the reliability of the interviews was supported by testing and confirming the qualitative research data provided by the male/female participants (Symeou, 2006).

\subsection{Utility of Research}

Research findings can be utilized in designing further training programs for school unit principals, in order to help them act as transformational leaders, and teachers in general, who should develop leadership skills, either as leaders in their classroom or mentors to their colleagues.

\subsection{Presentation and Analysis of Results}

\subsubsection{Demographic-Personal Data}

$42.1 \%$ of the 171 teachers who participated in the survey serve at secondary junior high schools, while $57.9 \%$ of them serve at high schools, with males being relatively less than males, at $36.8 \%$ versus $63.2 \%$, respectively. In terms of the employment relationship, an overwhelming proportion of $98.2 \%$ of the teachers are permanent at the schools. The majority of teachers have worked for many years in education, and this finding shows that teachers have prior experience of working with at least one school principal, as well as of the leadership behaviors and practices that may or may not cause job satisfaction at school.

\subsubsection{Descriptive Characteristics of the Level of Job Satisfaction}

The responding teachers recorded their views in 27 question-statements about the level of general job satisfaction. This was followed by the calculation of the mean value for each respondent. The mean value for the questions of the first questionnaire was found to be $4.4 \pm 0.47(\mathrm{~N}=169)$. Even if the two answers that did not comply were replaced by some mean value, the mean value of all the answers would be infinitesimally affected, and any impact on the result would be negligible. Therefore, the mean value is higher than the theoretical central value 3 and equates with/amounts to $88 \%$ of maximum job satisfaction. Furthermore, a standard deviation can be observed in the responses, i.e. $s=0.47$, which is lower than 1 . Consequently, the responses are fairly concentrated close to the "view" that is determined by the mean value, i.e. 4 , which refers to a high level of satisfaction.

Table 1. Descriptive characteristics of the level of job satisfaction

\begin{tabular}{ccc}
\hline $\mathrm{N}$ & Mean value & Standard Deviation \\
\hline 169 & 4.4 & 0.47
\end{tabular}

\subsubsection{Differences in the Level of Job SatisfactionWithin the Sample}

The investigation of the differences in the indicators that reflect the contribution of transformational leadership did not yield any statistically significant differences in the general level of job satisfaction among secondary and high school 
teachers. This conclusion can be drawn from the t-test for the indicator that refers to the mean value, where it was found out that $\mathrm{p}=0.840>0.05(\mathrm{t}=0.203$, d.f. $=167, \mathrm{~N} 1=98, \mathrm{~N} 2=71)$ with equal dispersions from Levene's test $(\mathrm{p}=0.568>0.05)$. Therefore, the minor difference in mean values is not regarded as statistically significant, and therefore, regardless of the school type (secondary or high school), the teachers stated approximately the same mean value of job satisfaction in the questionnaire (Tables 2, 3).

Table 2. Job satisfaction with regard to the school unit type

\begin{tabular}{cccc}
\hline School Unit Type & $\mathrm{N}$ & Mean value & Standard Deviation \\
\hline High School & 98 & 4.40 & 0.48 \\
\hline Secondary School & 71 & 4.39 & 0.46 \\
\hline type through t-test & & &
\end{tabular}

Table 3. Correlation of job satisfaction mean values with regard to the school unit

\begin{tabular}{lcccccc}
\hline & \multicolumn{3}{c}{$\begin{array}{c}\text { Levene's Test on } \\
\text { Equality of Dispersions }\end{array}$} & & & t-test \\
& & $\mathrm{F}$ & $\mathrm{p}$ & $\mathrm{t}$ & $\mathrm{d} . f$. & $\mathrm{p}$ \\
\hline Assumed Equality of Dispersions & 0.327 & 0.568 & 0.203 & 167 & $0.840^{*}$ \\
\hline Note. ${ }^{*} \mathrm{p}=0.840>0.05$, two-tailed. & & & & & & \\
\hline
\end{tabular}

In terms of the overall educational service of the respondents, descriptive table 4 illustrates a drop in general job satisfaction as a result of the application of transformational leadership, in the category of total teaching service over 29 years, i.e. in relatively older teachers, compared to other categories. Moreover, a downward trend is also noticed in the category of total teaching service between 24-29 years (Table 4).

Table 4. Job satisfaction with regard to total teaching service (Years)

\begin{tabular}{cccc}
\hline Total Teaching Service (Years) & $\mathrm{N}$ & Mean value & Standard Deviation \\
\hline$<12$ & 22 & 4.47 & 0.59 \\
\hline $12-17$ & 42 & 4.52 & 0.29 \\
\hline $18-23$ & 39 & 4.42 & 0.43 \\
\hline $24-29$ & 33 & 4.33 & 0.42 \\
\hline$>29$ & 33 & 4.23 & 0.61 \\
\hline Total & 169 & 4.4 & 0.47
\end{tabular}

In order to identify possible statistically significant differences among the categories of service, Levene's variance homogeneity test was performed in the beginning, where, under null hypothesis, dispersions are equal, and was found that $\mathrm{p}=0.012<0.05$ ( $\mathrm{F}=3.298$, d.f. $1=4$, d.f. $2=164)$, and therefore, variance homogeneity in service categories is rejected. This fact casts doubts on the/implies little confidence in the ANOVA test (where, however, $p=0.093>0.05$ ), and therefore, the Kruskal-Walis non-parametric test was performed. Since $\mathrm{p}=0.129>0.05$, no statistically significant differences emerge among the distributions of satisfaction within the categories that refer to the years of service. (Tables 5, 6, 7)

Table 5. Criterion of variance homogeneity on job satisfaction with regard to total teaching service (Years)

\begin{tabular}{cccc}
\hline Levene's F & d.f.1 & d.f. 2 & $\mathrm{p}$ \\
\hline 3.298 & 4 & 164 & 0.012
\end{tabular}

Table 6. Variance test about job satisfaction with regard to total teaching service (Years)

\begin{tabular}{cccccc}
\hline & \multicolumn{5}{c}{ ANOVA } \\
\cline { 2 - 6 } & Sum of Squares SS & d.f. & Mean Square MS & F & p \\
\hline Between Groups & 1.731 & 4 & 0.433 & 2.026 & 0.093 \\
\hline Within Groups & 35.030 & 164 & 0.214 & & \\
\hline Total & 36.762 & 168 & & & \\
\hline
\end{tabular}

Table 7. Kruskal-Walis variance homogeneity test on job satisfaction per group with regard to total teaching service (Years)

\begin{tabular}{ccccccccc}
\hline GROUP (within) & 1 & 2 & 3 & 4 & 5 & 6 & 7 & Among groups \\
\hline $\mathrm{p}$ & 0.240 & 0.426 & 0.112 & 0.412 & 0.445 & 0.265 & 0.432 & $0.129^{*}$ \\
\hline Note. $^{*} \mathrm{p}=0.129>0.05$ & & & & & & & \\
\hline
\end{tabular}




\subsubsection{Results of the Interviews}

The key findings of the interviews confirm the findings of the quantitative survey and focus on seven conceptual groups of the questionnaire: building a shared vision, accepting shared goals, developing high performance expectations, providing personalized support, igniting mental stimulation, serving as a role model and providing values, and building partnerships and cooperation.

\section{Conclusions/Discussion}

The data analysis leads to the results, which comprise the responses provided to the research questions.

Regarding the first research question, i.e. to what extent do teachers believe that transformational leadership contributes to their professional development, it is evident that this happens to a very great extent. This view has also been highlighted in earlier surveys (Sayadi, 2016; Tesfaw, 2014; Eliophotou, 2014; Golia, 2014; Aydin et al., 2013; Kieres \& Gutmore, 2014; Barnett et al., 2005; Bogler, 2001, 2002), with the provision of individualized support being the factor with the highest contribution to the professional development of teachers (Kieres et al., 2014, Eliophotou, 2014, Barnett et al., 2005; Aydin et al., 2013). Transformational leadership generates satisfaction, because it is associated with a high level of motivation at work, corresponding to the teacher's needs for recognition, achievement, assumption of responsibility, autonomy, and self-actualization (Bentea et al., 2012). This is accomplished through a grid of sound interpersonal and supportive relationships among all the stakeholders of the school, namely between principal and teacher, as well as among teachers.

In terms of the second research question, i.e. whether views differ about the assumption that transformational leadership contributes to job satisfaction depending on the school type, the survey showed that views do not differ. This is a view that is not supported by literature citations in other recent empirical surveys. However, the interviews that were taken within the context of this survey led to the conclusion that views do not differ. The teacher, whether he or she serves at a secondary or high school, under a leadership that behaves and acts in a transformational way, can experience general job satisfaction to a large extent. By attempting to interpret this conclusion, it can be argued that, since the transformational leader can correspond to the need for reform and inspire his or her associates, secondary education, which has attracted the government's attention over the last years, in order to implement reforms, needs transformational leaders (Leithwood, 1994).

As per the third research question, i.e. whether the views differ about the assumption that transformational leadership contributes to job satisfaction according to the total teaching service, the survey showed that views do not differ. This view has also been highlighted by other empirical surveys (Bogler, 2002). The teacher can experience general job satisfaction to a large extent with the application of transformational leadership, regardless of the total years of his or her teaching service. In an attempt to interpret this finding, the practices and behavior of a transformational leader manifest an effective and successful way of applying leadership for both newer and older in-service teachers, due to its engaging and human-centered nature, as well as due to the robust system of personalization that it incorporates (OECD, 2014; Pasiardis, 2012).

As far as practical implications are concerned, this research can offer insights for educational policy makers, school managers, teachers and researchers in the field of educational research. Of course, transformational leadership is a style of management with many characteristics and various aspects and in the present paper, not all of these aspects were examined. However, although this study has relevant limitations, its results can be useful and provide a starting point for future research on various aspects of this issue.

\section{Acknowledgements}

The authors would like to thank the fellow male and female teachers who participated in the survey and agreed to fill in the questionnaire, showing great willingness to express their views in the interviews. Also, the authors would like to thank the reviewers and the editor of this journal for their valuable comments on an earlier version of this manuscript and Joan Macphail for her contribution to the manuscript's language editing.

\section{References}

Adams, B., \& Bailey, G. (1989). School Is For Teachers: Enhancing The School Environment. NASSPB Bulletin, 73, 44-48.

Aydin, A., Sarier, Y., \& Uysal, S. (2013). The Effect of School Principals' Styles on Teachers' Organizational Commitment and Job Satisfaction.Educational Sciences. Theory \& Practice, 13(2), 806-811.

Barnett, M. A., Marsh, W. H., \& Craven, G. R. (2005). What Type of School Leadership Satisfies Teachers? A Mixed Method Approach to Teachers' Perceptions of Satisfaction.Paper presented at the AARE Annual Conference. Sydney: Parramatta. Available at http://www.aare.edu.au/data/publications/2005/bar05419.pdf (1/2/2017)

Bass, B. M., \& Riggio, R. E. (2014). Transformational leadership (2 $2^{\text {nd }}$ ed.). New York: Routledge

Bass, M. B. (1985). Leadership and Performance Beyond Expectations.New York: Free Press. 
Bentea, C. C., \& Anghelache, V. (2012). Teachers' Motivation and satisfaction for professional activity. Procedia-Social and Behavioral Sciences, 33, 563-567. https://doi.org/10.1016/j.sbspro.2012.01.184

Bogler, R. (2001). The Influence of Leadership Style on Teacher Job Satisfaction.Educational Administration Quarterly, 37(5), 665-673.

Bogler, R. (2002). Two profiles of schoolteachers: a discriminant analysis of Teacher Job Satisfaction. Teaching and Teacher Education, 18, 662-683.

Bolin, F. (2008). A Study of Teacher Job Satisfaction and Factors That Influence It. Chinese Education and Society, 40 (5), 47-64.

Bourantas, D. (1992). Management. Organizational Theory and Behavior (in Greek) Athens: Team

Chamundeswari, S. (2013). Job Satisfaction and Performance of School Teachers.International Journal of Academic Research in Business and Social Sciences, 3(5), 420-428.

Cohen, L., Manion, L., \& Morisson, K. (2008). Methodology of teaching research (trans. S. Kyranakis, M. Mavraki.C. Mitsopoulou, P. Bithara\& M. Filopoulou). Athens: Metaixmio

Dafermos, V. (2011). Social statistics and Research methodology with SPSS, Thessaloniki: Ziti

Drenth, J. D. P, Thierry, H., \& Wolff, J. C. (1998). Handbook of Work and Organizational Psychology (Vol. 4: Organizational Psychology) ( $2^{\text {nd }}$ ed.). UK: Psychology Press Ltd.

Eliophotou-Menon, M. (2014). The relationship between transformational leadership, perceived leader effectiveness and teachers' job satisfaction. Journal of Educational Administration, 52(4), 509-528.

Eliophotou-Menon, M., \& Ioannou, A. (2016). The link between transformational leadership and teachers' job satisfaction, commitment, motivation to learn, and trust in leader. Academy of Educational Leadership Journal, 20(3), 12-22.

Eliophotou-Menon, M., \&Reppa-Athanasoula, A. (2011). Job Satisfaction among Secondary School Teachers: The Role of Gender and Experience. School Leadership \& Management, 30(5), 435-450.

Field, A. (2009). Discovering Statistics using SPSS ( $3^{\text {rd }}$ ed.). London: Sage Publications, Inc.

Geijsel, F., Sleegers, P., Leithwood, K., \& Jantzi, D. (2002). Transformational leadership effects on teachers' commitment and effort toward school reform. Journal of Educational Administration, 41(3), 228-256.

Given, M. L. (Ed.) (2008). The Sage encyclopedia of qualitative research methods.Volumes $1 \& 2$. Thousand Oaks, CA: Sage Publications, Inc.

Golia, A. (2014). Transformational leadership and teacher job satisfaction: the role of self-efficacy. Doctoral dissertation, University of Thessaly, 2014). Available on the webpage of the National Documentation Centre (EKT) at http://www.openarchives.gr/view/2688041 (30/1/2017)

Griffin, K. D. (2010). A Survey of Bahamian and Jamaican Teachers' Level of Motivation and Job Satisfaction.Journal of Invitational Theory and Practice, 16, 56-76.

Griffith, J. (2004). Relation of principal transformational leadership to school staff job satisfaction, staff turnover, and school performance. Journal of Educational Administration, 42(3), 333-356. https://doi.org/10.1108/09578230410534667

Hutabarat, W. (2015). Investigation of Teacher Job-Performance Model: organizational Culture, Work Motivation and Job-Satisfaction. Asian Social Science, 11(18), 295-304.

Isac, N., \& Badshah, W. M. (2016). Motivation and job satisfaction of human resources within an organization.Scientific Bulletin-Economic Sciences, 15(1), 33-40.

Jacobson, P. (1976). Introduction to Statistical Measures for the Social \& Behavioral Sciences. Hinsdale: Dryden Press.

Jantzi, D., \& Leithwood, K. (1995). Toward an Explanation of How Teachers' Perceptions of Transformational School Leadership are Formed. Paper presented at the Annual Meeting of the American educational Research Association, April 18-22, 1995 (pp. 2-38). CA: San Francisco.

Jantzi, D., \& Leithwood, K. (1996).Toward an Explanation of Variation in Teachers' Perceptions of Transformational School Leadership.Educational Administration Quarterly, 32(4), 512-538.

Kampouridis, G. (2002). Organizational and management of school units. Athens: Klidarithmos.

Kantas, A. (1993). Organizational-Industrial Psychology. Part $1^{\text {st }}$ : Incentives-Job satisfaction-Leadership. Athens: 
EllinikaGrammata

Kanungo, N. R. (2001). Ethical Values of Transactional and Transformational Leaders. Canadian Journal of Administrative Sciences, 18(4), 257-265. https://doi.org/10.1111/j.1936-4490.2001.tb00261.x

Katsaros, I. (2008). Organization and Management of Education. Athens: YPEPTH-PI

Kefis, N. V. (2005). Integrated Management Key principles for modern economic units. Athens: Kritiki

Kieres, H. K., \& Gutmore, D. (2014). A study of the Value Added by Transformational Leadership Practices to Teachers' Job Satisfaction and Organizational Commitment.Educational Leadership Review of Doctoral Research, 1(1), 175-184.

Leithwood, K. (1992). The move toward transformational leadership.Educational Leadership, 49(5), 8-12.

Leithwood, K. (1994). Leadership for School Restructuring.Educational Administration Quarterly, 30(4), 498-518.

Leithwood, K., \& Beatty, B. (2008). Leading with Teacher Emotions in Mind. Thousand Oaks, CA: Corwin Press.

Leithwood, K., \& Jantzi, D. (1999a). Transformational School Leadership Effects: A Replication. School Effectiveness and School Improvement, 10(4), 451-479.

Leithwood, K., \& Jantzi, D. (2000). The effects of transformational leadership on organizational conditions and student engagement with school. Journal of Educational Administration, 38(2), 112-129.

Leithwood, K., \& Sun, J. (2012). The Nature and Effects of Transformational School Leadership: A Meta-Analytic Review of Unpublished Research. Educational Administration Quarterly, 48(3), $387-423$. https://doi.org/10.1177/0013161X11436268

Leithwood, K., Jantzi, D., \& Steinbach, R. (1999b). Changing leadership for changing times. Buckingham: Open University Press.

Lowenberg, G., \& Conrad, A. K. (1998). Industrial/Organizational Psychology. New York: Allyn\& Bacon.

Meng, J., \& Chin, C. (2007). Meta-analysis of Transformational School Leadership Effects on School Outcomes in Taiwan and the USA. Asia Pacific Education Review, 8(2), 166-177.

Mullins, J. L. (2007). Management and Organisational behaviour ( $8^{\text {th }}$ ed.). Harlow, England: Financial Times Prentice Hall.

Nguni, S., Sleegers, P., \& Denessen, E. (2006). Transformational and transactional leadership effects on teachers' job satisfaction, organizational commitment, and organizational citizenship behavior in primary schools: The Tanzanian case. School Effectiveness and School Improvement, 17(2), 145-177. https://doi.org/10.1080/09243450600565746

OECD. (2014). What Helps Teachers Feel Valued and Satisfied with their Jobs? Teaching in Focus, 5, 1-4. Available on the webpage of the OECD Library at: http://www.oecd-ilibrary.org/education/teaching-in-focus 23039280

Ostroff, C. (1992). The Relationship between Satisfaction, Attitudes, and Performance: An Organizational Level Analysis. Journal of Applied Psychology, 77, 963-974.

Pasiardis, P. (2012). Successful school principals (in Greek) Athens: Ion

Raptis, N. (2006). The management innovation in school leadership.Scientific Rostrum, 6, 32-42.

Reppa, A. A. (2008). Educational Management \& Organizational Behavior.Pedagogy of Management in Education. Athens: Ellin

Robbins, P. S., \& Judge, A. T. (2011). Organizational behavior Key Concepts and Contemporary Approaches (trans. A. Plataki). Athens: Kritiki

Robson, C. (2011). Real world research: $3^{\text {rd }}$ Edition. Chichester. John Wiley \&Sons Ltd

Saif, K. S., Nawaz, A., Jan, A. F., \& Khan, I. M. (2012). Synthesizing the theories of job satisfaction across the cultural / attitudinal dimensions.Interdisciplinary Journal of Contemporary Research in Business, 3(9), 1382-1396.

Saiti, A., \& Papadopoulos, Y. (2015). School teachers' job satisfaction and personal characteristics.A quantitative research study in Greece, 29(1), 73-97. ISSN: ISSN-0951-354X

Sayadi, Y. (2016). The effect of dimensions of transformation, transactional, and non-leadership on the job satisfaction and organizational commitment of teachers in Iran. Management in Education, 30(2), 57-65. https://doi.org/10.1177/0892020615625363

Spilt, L. J., Koomen, M. Y. H., \& Thijs, J. (2011). Teacher Wellbeing: The Importance of Teacher-Student Relationships. Educational Psychology Review, 23, 457-477. 
Symeou, L. (2006). Validity and reliability in qualitative research: The paradigm of a survey on the cooperation between school-family. Proceedings of the $9^{\text {th }}$ Conference of the Pedagogical Society of Cyprus, Nicosia, 2nd-3rd of June 2006. Available at http://www.pek.org.cy/proceedings.html (23/3/2017)

Tesfaw, A. T. (2014). The relationship between transformational leadership and job satisfaction: The case of government secondary school teachers in Ethiopia. Educational Management Administration \& Leadership, 42(6), 903-918. https://doi.org/10.1177/1741143214551948

Theofilidis, C. (2012). School leadership and management.From Bureaucracy to transformational leadership. Athens: Grigoris

Tosi, L. H., Mero, P. N., \& Rizzo, R. J. (2000). Managing Organizational Behavior (4 ${ }^{\text {th }}$ ed.). Cambridge, Mass: Blackwell Publisher Inc.

Tucker, A. B., \& Russell, F. R. (2004). The influence of the transformational leader. Journal of Leadership and Organizational Studies, 10(4), 103-111.

Vakola, M., \& Nikolaou, I. (2012). Organizational Psychology and Behavior. Athens: Rosili

Vasileiadou, D., \& Dieronitou, E. (2014). The application of transformational leadership to education.Review of Teaching-Scientific Issues, 3, 92-108.

Vecchio, P. R. (1995). Organizational Behavior ( $3^{\text {rd }}$ ed.). The Dryden Press

Yukl, G. (2010). Leadership in Organizations (7th ed). New Jersey: Prentice Hall

Zournatzi, E., Tsiggilis, N., Koustelios, A., \& Pintzopoulou, E. (2006). Job satisfaction of physical education teachers in primary and secondary education. Sports and Recreation Management, 3(2), 18-28.

\section{Copyrights}

Copyright for this article is retained by the author(s), with first publication rights granted to the journal.

This is an open-access article distributed under the terms and conditions of the Creative Commons Attribution license which permits unrestricted use, distribution, and reproduction in any medium, provided the original work is properly cited. 